\title{
TEACHER LEADERSHIP: GOING BEYOND CLASSROOM
}

Studies have observed the positive effects that leadership can have on schools (Adams, Kutty \& Zabidi, 2017; Jones, et. al., 2015; Harris, et. al., 2017; Perera, Adams, \& Muniandy, 2015). Leithwood, Louis, Anderson, and Wahlstrom (2004) reiterated that "Leadership is second only to classroom instruction among all school-related factors that contribute to what students learn at school" (p. 5). The school effectiveness and improvement field face a new and pervasive challenge (Harris, et. al, 2015). The past few decades have seen teacher leadership emerge as an important aspect of school leadership (Wenner \& Campbell, 2017). Teacher leadership is no longer optional, teachers have developed an increasingly important role in their schools. Teacher leadership is now the significant means to inspire the enhancement of teaching (Muijs \& Harris, 2006).

In the current stage of instructional development, teachers' routines are no longer restricted within classroom boundaries (Grant, 2006). Teachers are in a unique position to promote change within schools (Mangin \& Stoelinga, 2010), by leading the spread of best practices through teacher collaboration, encouraging teacher professional learning and focus on content-specific issues due to their familiarity with the complexities involved in teaching (Wenner \& Campbell, 2017; Curtis, 2013; Muijs \& Harris, 2006). Both in formal and informal positions; teacher leaders are identified as critical resources for instructional and school improvement (Fairman \& Mackenzie, 2012; Harrison \& Killion, 2008; Mangin \& Stoelinga, 2010).

However, the increasing call for teachers to engage in leadership action (Fairman \& Mackenzie, 2012) are blurred by ambiguous meaning between formal and informal leaders which led to Katzenmeyer and Moller (2009) to assert that:

'Teacher leaders lead within and outside of the classroom. A teacher leader is a member and contributor to a community of teacher learners. They are influential in the continued improvement of educational practice; and accept responsibility for achieving the outcomes of their leadership' (p.6)

The conceptualizations of the term teacher leader and what exactly its meant still vary widely (Wenner \& Campbell, 2017). This is further complicated by the fact that often, teacher leaders do not hold the same titles across schools. Teacher leaders were given titles such as mentor teacher, specialist, department chair, coach among the few named within the literature (Mangin \& Stoelinga, 2008; Neumerski, 2012). Neumerski (2012) highlights "there is little consensus around what constitutes 'teacher leadership' . . . it tends to be an umbrella term referring to a myriad of work" (p. 320). In many cases, the definition and criteria of teacher leadership may be influenced and implied within the organizational structure (Smylie \& Denny, 1990).

Prominently, teacher leadership looks unique for every teacher. Teacher leaders arise from various backgrounds, and with an extensive variety of skills. However, they share a common desire - to use those skills for students' benefit and to improve learning. Leading Educators (2015) describes teacher leaders as teachers who are willing to step up and step out of their classrooms to assist in school, district, state, or national policy leadership 
capacities, thus which help to shape and finally implement the strategies that best support student learning. Teacher leaders make a conscious choice to take up leadership role which entails taking time and effort to serve others (Ketzenmeyer \& Moller, 2009).

Teacher leadership has of late become an increasingly popular topic among educational policymakers and influential educational organizations as an important component of school reform (Wenner \& Campbell, 2017). It is obvious there is a great need for empirical research on teacher leadership. Wenner and Campbell (2017) highlights "No comprehensive literature review of empirical research has been completed over the last decade since tremendous shifts in policy and other influences have coalesced to reshape the educational landscape." (p. 2).

The potentiality of teacher leaders to fit into a variety of positions and meet the needs of any situation becomes precarious when the need and demand for more teacher leaders in schools is not well supported by rigorous, empirically based evidence. Perhaps it's the "complication" of the teacher leadership concept, factors that inhibit its effectiveness and the struggles teacher leaders encounter that will intrigue researchers to fill the gaps in knowledge.

\section{REFERENCES}

Adams, D., Raman Kutty, G. \& Mohd Zabidi, Z. (2017). Educational Leadership for the 21st Century. International Online Journal of Educational Leadership, 1(1), 1-4.

Curtis, R. (2013). Findings a new way: Leveraging teacher leadership to meet unprecedented demands. Washington, DC: Aspen Institute.

Fairman, J. C., \& Mackenzie, S. V. (2012). Spheres of teacher leadership action for learning. Professional development in education, 38(2), 229-246.

Grant, C. (2006). Emerging Voices on Teacher Leadership: Some South African Views. Educational Management Administration \& Leadership, 34(4), 511-532.

Harris, A., Jones, M., Cheah, K. S. L., Devadason, E., \& Adams, D. (2017). Exploring principals' instructional leadership practices in Malaysia: insights and implications. Journal of Educational Administration, 55(2), 207-221.

Harris, A., Adams, D., Jones, M. S., \& Muniandy, V. (2015). System Effectiveness and Improvement: The Importance of Theory and Context. School Effectiveness and School Improvement, 26(1), pp. 1-3

Harrison, C., \& Killion, J. (2008). Ten Roles for Teacher Leaders. Educational Leadership, 65(1), 1-5.

Katzenmeyer, M., \& Moller, G. (2009). Awakening the sleeping giant: Helping teachers develop as leaders. $3^{\text {rd }}$ Ed. Thousand Oaks, CA: Sage.

Leading Educators. (2015). Teacher Leader Competency Framework. Retrieved from http://www.saiowa.org/Schreifer_TLcompetencyframework2015.pdf\%5Cnhttp:// www.leadingeducators.org/publications

Leithwood, K., Louis, K., Anderson, S. and Wahlstrom, K. (2004). How leadership influences student learning (New York: The Wallace Foundation).

Jones, M., Adams, D., Hwee Joo, M. T., Muniandy, V., Perera, C. J., \& Harris, A. (2015). Contemporary challenges and changes: principals' leadership practices in Malaysia. Asia Pacific Journal of Education, 35(3), 353-365. 
Mangin, M. M., \& Stoelinga, S. R. (2010). The future of instructional teacher leader roles. Educational Forum, 74(1), 49-62.

Mangin, M. M., \& Stoelinga, S. R. (2008). Teacher leadership: What it is and why it matters. In M. M. Mangin \& S. R. Stoelinga (Eds.), Effective teacher leadership: Using research to inform and reform (pp. 1-9). New York, NY: Teachers College Press.

Muijs, D., \& Harris, A. (2006). Teacher led school improvement: Teacher leadership in the UK. Teaching and Teacher Education, 22(8), 961-972.

Neumerski, C. M. (2013). Rethinking Instructional Leadership, a Review : What Do We Know About Principal, Teacher, and Coach Instructional Leadership, and Where Should We Go From Here? Educational Administration Quarterly, 49(2), 310-347.

Perera, C. J., Adams, D. and Muniandy, V. (2015), "Principal Preparation and Professional Development in Malaysia: Exploring Key Influences and Current Practice",in A. Harris and M. Jones (Eds.), Leading Futures: Global Perspectives on Educational Leadership, SAGE press, London, pp. 125-137.,

Smylie, M. A., \& Denny, J. W. (1990). Teacher leadership: tensions and ambiguities in organizational perspective. Educational Administration Quarterly, 26(3), 235-259.

Wenner, J. A., \& Campbell, T. (2017). The theoretical and empirical basis of teacher leadership: A review of the literature. Review of Educational Research, 87(1), 134171.

Donnie Adams

Editor of International Online Journal of Educational Leadership Institute of Educational Leadership, Faculty of Education, University of Malaya donnieadams@um.edu.my

and Syafizza Norida Bt. A. Samat and Humamuddin Bin Abu Samah Institute of Educational Leadership, Faculty of Education, University of Malaya 